\title{
Articulo especial: Obras maestras del arte universal y la medicina: Finnegans Wake de James Joyce (1882 -1941)
}

Universal art masterpieces and medicine: Finnegans Wake by James Joyce (1882 -1941)

Carlos G. Musso*

Musso CG. Finnegans Wake de James Joyce (1882 -1941). Evid Act Pract Ambul. Jul-Sep 2013;16(3):95

\section{Descripción y análisis de la obra}

Se trata de un relato de tipo onírico, que como tal, cumple con las leyes que rigen la elaboración de los sueños (Freud): lógica fantástica, disolución de las coordenadas temporo-espaciales y múltiples juegos metafóricos y metonímicos. Consiste en el relato de un sueño, el de toda la humanidad, que comienza en una edad dorada en la que el gigante Finnegan (antigua balada irlandesa) se cae de una escalera y muere al golpearse su cabeza (muerte). Sus restos son velados (wake) por su esposa y conocidos, el gigante se transforma en la ciudad de Dublin (el mito de Fionn Mac Cumhail) y su viuda deviene el río que la atraviesa (Liffey). Sigue luego una edad de bronce donde Finnegan es Humphrey Chimpden Earwicker (HCE), encargado de un pub, y su mujer es Anna Livia Plurabelle (ALP). La pareja posee dos mellizos varones y rivales (fraticidio): Shem (escritor) y Shaun (cartero), y una hija (Issy). Las identidades de estos personajes sufren múltiples trasmutaciones a lo largo del relato (metonimia y metáfora).

Algunos científicos sostienen que las producciones oníricas poseen un rol fisiológico consistente en recrear eventos amenazantes propios de la vida de vigilia, con el fin de mantener entrenadas las respuestas adaptativas correspondientes a evitar dichos peligros: huida, ocultamiento, etc. Sería un mecanismo heredado de nuestros más remotos ancestros y merced al cual ellos fueron capaces de sobrevivir a la hostilidad del mundo prehistórico. Esto explicaría por qué las temáticas de los sueños son predominantemente situaciones de miedo o angustia, generadas por monstruos, animales (predadores) u otros seres humanos (luchas tribales). En consonancia con esta interpretación neurobiológica, los contenidos oníricos de Finnegans Wake se basan en las pesadillas más horrorosas de la humanidad: el incesto, el filicidio, el parricidio, el fraticidio, la traición, el triunfo del mal y el amor trágico. Así por ejemplo, vemos que en este sueño, HCE se ve envuelto en una serie de rumores de orden criminal e incestuoso. ALP le dicta a su hijo Shem una carta en pos de exculpar/inculpar a su esposo, y luego se la entrega a Shaun, quien nunca la despacha (traición). Los mellizos, no sólo se disputan a su hermana (incesto y fraticidio), sino que además buscan desplazar a HCE del pub (parricidio). HCE, una vez que se retiran los clientes, cierra el negocio. Luego aparecen alusiones a los cuatro evangelistas (religión), a la leyenda de Tristán e Isolda (amor trágico), y al triunfo de Shaun (Caín) sobre Shem (Abel) (el triunfo del mal sobre el bien). Con el surgimiento de una nueva era (era de hierro) la familia Earwicker deviene la familia Porter. En la madrugada, los esposos hacen el amor (sexo), pero se ven interrumpidos por el llanto (sufrimiento) de uno de sus hijos acongojado (angustia) a raíz de una pesadilla que involucra a su padre (filicidio). La madre se levanta a consolarlo tras lo cual regresa con su marido. El metafórico canto de un gallo (sexo) anuncia el despuntar del día. El sueño finaliza con un monólogo de ALP, quien intenta despertar a HCE (wake), y ella, como río que es, retorna al océano (el origen) para volver a comenzar el relato en un ciclo sin fin. Se trata entonces de un relato (sueño) de carácter recurrente, ya que la frase que lo cierra se continúa con la que lo inicia, en una clara alegoría al carácter cíclico de la historia de la humanidad (Giambattista Vico) con sus sucesivas etapas (Ovidio). Concluimos entonces que la obra Finnegans Wake de James Joyce recrea en forma excepcional los contenidos y la dinámica de las producciones oníricas humanas.

Recibido el 30/06/2013 y aceptado el 01/07/2013

\footnotetext{
Referencias

1. Joyce J. Finnegans wake. New York. Penguin Books. 1976.

2. Musso CG, Enz P. La empatía en la obra de James Joyce (parte I). Arte y Medicina.2012;6:69-70.

3. Freud S. La interpretación de los sueños. Buenos Aires. Losada. 1997.

4. Fromm E. El lenguaje olvidado. Barcelona. Paidós. 2012.

5. Revonsuo A. The reinterpretation of dreams: An evolutionary hypothesis of the function of dreaming. Behavioral and Brain Sciences. 2000; 23:793-1121

6. Desseilles M, Thien T, Sterpenich V, Schwartz S. Cognitive and emotional processes during dreaming: A neuroimaging view. Consciousness and cognition. 2011; 20: 9981008

7. Bute M. Passages from Finnegans Wake. 1966 (film)
}

*Servicio de Nefrología del Hospital Italiano de Buenos Aires carlos.musso@ hospitalitaliano.org.ar 